\title{
The Role of Extracellular Regulated Kinases I/II in Late-Phase Long-Term Potentiation
}

\author{
Kobi Rosenblum, Marie Futter, Karen Voss, Muriel Erent, Paul A. Skehel, Pim French, Louis Obosi, \\ Matt W. Jones, and Tim V. P. Bliss
}

Division of Neurophysiology, National Institute for Medical Research, London NW7 1AA, United Kingdom

\begin{abstract}
Extracellular regulated kinases (ERKI/II), members of the mitogen-activated protein kinase family, play a role in long-term memory and long-term potentiation (LTP). ERKI/II is required for the induction of the early phase of LTP, and we show that it is also required for the late phase of LTP in area CA1 in vitro, induced by a protocol of brief, repeated $100 \mathrm{~Hz}$ trains. We also show that ERKI/II is necessary for the upregulation of the proteins encoded by the immediate early genes Zif268 and Homer after the induction of LTP in the dentate gyrus by tetanic stimulation of the perforant path in vivo or by BDNF stimulation of primary cortical cultures. To test whether the induction of persistent synaptic plasticity by stimuli such as BDNF is associated with nuclear translocation of ERKI/II, we expressed enhanced green fluorescent protein (EGFP)-ERKII in PC12 cell
\end{abstract}

lines and primary cortical cultures. In both preparations, we observed translocation of EGFP-ERKII from the cytoplasm to the nucleus in cells exposed to neurotrophic factors. Our results suggest that the induction of late LTP involves translocation of ERKI/II to the nucleus in which it activates the transcription of immediate early genes. The ability to visualize the cellular redistribution of ERKII after induction of long-term synaptic plasticity may provide a method for visualizing neuronal circuits underlying information storage in the brain in vivo.

Key words: mitogen-activated protein kinase; long-term potentiation; hippocampus; brain-derived neurotrophic factor; Zif268; immediate early genes; enhanced green fluorescent protein
Inhibitors of extracellular regulated kinase (ERKI/II), in common with inhibitors of protein synthesis, affect long-term memory without impairing short-term memory (Davis and Squire, 1984; Walz et al., 2000). A role for ERKI/II in long-term memory has been demonstrated in a number of different learning paradigms in invertebrates and vertebrates (Bailey et al., 1997; Martin et al., 1997; Atkins et al., 1998; Berman et al., 1998; Crow et al., 1998; Blum et al., 1999). Signaling pathways using ERKI/II are excellent candidates for transducing long-term changes in neuronal gene expression and function triggered by extracellular stimuli. In neurons, ERKI/II can be activated by at least three neurotransmitters or modulators known to induce long-term plasticity: glutamate, acetylcholine, and BDNF (Nakamura et al., 1996; Rosenblum et al., 2000). In other cell types, ERKI/II translocates to the nucleus and modulates gene expression after differentiationinducing stimulation (Marshall, 1995). In Aplysia, it has been

Received Dec. 25, 2001; revised April 16, 2002; accepted April 16, 2002.

This work was supported in part by a Royal Society fellowship to K.R. and European Commission Grant BIO4-CT98-0333. We thank Luca Raimondi and Grant Roalfe for the excellent preparation of primary neuronal cultures, Dr. Abdul Sesay for help with the preparation of PC12 cells, and Dr. Alan Fine for useful discussions.

Correspondence should be addressed to Dr. K. Rosenblum at his present address: Center for Brain and Behavior, University of Haifa, Haifa 31905, Israel. E-mail: kobir@psy.haifa.ac.il.

M. Futter's present address: Molecular and Cellular Neuroscience, Rockefeller University, 1230 York Avenue, Box 296, New York, NY 10021.

M. Erent's present address: Max Planck Institute for Medical Research, Department of Biophysics, Jahnstrasse 29, Heidelberg, D-69120 Germany.

P. A. Skehel's present address: Department of Neuroscience, University of Edinburgh, 1, George Square, Edinburgh, EH8 9JZ, UK.

P. French's present address: Department of Anatomy, Erasmus University, P.O. Box 1738, Rotterdam, The Netherlands.

M. W. Jones' present address: Center for Learning and Memory, Massachusetts Institute of Technology, 77 Massachusetts Avenue, Cambridge, MA 02139.

Copyright (C) 2002 Society for Neuroscience $0270-6474 / 02 / 225432-10 \$ 15.00 / 0$ reported that ERKI/II homologs are translocated to the nucleus after repetitive applications of 5-HT that induce long-term facilitation but not by a single application that induces only transient facilitation (Martin et al., 1997). In the rat hippocampal slice, inhibition of ERKI/II leads to an attenuation of tetanus-induced long-term potentiation (LTP) and of the response of a cAMP response element-regulated transcriptional reporter (Impey et al., 1998). A number of studies have shown that activation of ERKI/II is both necessary for and correlated with tetanusinduced LTP in the hippocampus (English and Sweatt, 1997; Davis et al., 2000; Rosenblum et al., 2000, Patterson et al., 2001) and insular cortex (Jones et al., 1999). Here, we extend these studies and examine the role of ERKI/II regulation in the transcriptional response associated with the persistent expression of LTP. Our results indicate that ERKI/II is translocated to the nucleus and activates transcription of immediate early genes (IEGs) after plasticity-inducing stimulation of neurons.

\section{MATERIALS AND METHODS}

In vitro electrophysiology. Male Wistar rats (200-250 gm) were stunned, followed by dislocation of the spinal cord. The brain was rapidly removed and placed in cold, oxygenated artificial CSF (ACSF) (in mM: $120 \mathrm{NaCl}$, $3 \mathrm{KCl}, 2 \mathrm{MgCl}_{2}, 2 \mathrm{CaCl}_{2}, 1.2 \mathrm{NaH}_{2} \mathrm{PO}_{4}, 23 \mathrm{NaHCO}_{3}$, and 11 glucose). Hippocampi were dissected from the brain, and $410-\mu \mathrm{m}$-thick transverse slices were cut on a McIlwain tissue chopper. Slices were then either transferred to a submerged recording chamber and perfused with ACSF maintained at $28^{\circ} \mathrm{C}$ or temporarily stored for up to $5 \mathrm{hr}$ in a holding chamber in ACSF at room temperature. Slices were allowed to rest for at least $1 \mathrm{hr}$ in the recording chamber before recording began. Evoked population responses were obtained from area CA1 in response to stimulation of Schaffer collateral/commissural fibers. The intensity of the test stimulus was adjusted so that the slope of the field EPSP (fEPSP) was approximately one-half the maximum obtainable. LTP was induced by six trains (intertrain interval of $3 \mathrm{sec}$ ) of 20 pulses at $100 \mathrm{~Hz}$, at 1.5 times 
the baseline stimulation intensity. A control pathway, manipulated in parallel, was monitored throughout the experiment. The mitogenactivated protein kinase (MAPK) kinase (MEK) inhibitor PD98059 (38 $\mu \mathrm{M}$ in $0.2 \% \mathrm{DMSO}$ ) was added to the chamber at the indicated time points.

Whole animal electrophysiology. All procedures were performed in accordance with the United Kingdom Animals (Scientific Procedures) Act of 1986. Adult male rats (250-350 gm) were anesthetized with urethane $(1.5 \mathrm{gm} / \mathrm{kg}$, i.p. $)$ and mounted in a stereotaxic frame. Injection pipettes were lowered bilaterally to just above the dentate gyri $(4 \mathrm{~mm}$ caudal and $2.5 \mathrm{~mm}$ lateral to bregma, $2.8 \mathrm{~mm}$ below the pial surface). Concentric bipolar stimulating electrodes were placed bilaterally in the medial perforant path (4-4.2 mm lateral to lambda). Injections $(1 \mu \mathrm{l})$ of either $38 \mu \mathrm{M}$ PD098059 (test hemisphere) or $0.2 \%$ DMSO in saline (control hemisphere) were made over $10 \mathrm{~min}$, and the injection pipettes then were removed and replaced by micropipettes for recording (placed as for injections but $3.5 \mathrm{~mm}$ below the pial surface). Electrodes were positioned to maximize hilar field potentials evoked by perforant path stimulation; stimulation intensity was then set to evoke a $1-3 \mathrm{mV}$ population spike ( $60 \mu \mathrm{sec}$ pulses). Test responses were evoked at a frequency of $0.033 \mathrm{~Hz}$. Thirty minutes after drug or vehicle injection, tetanic stimulation was delivered to the perforant path (three trains of 50 pulses at $250 \mathrm{~Hz}, 30 \mathrm{sec}$ between trains). Test responses were sampled for an additional $20 \mathrm{~min}$, and the animals were then removed from the stereotaxic frame in preparation for dissection.

Statistics. Mean \pm SEM values are given throughout. Drug effects on the level of potentiation in different groups of animals were compared using the unpaired Student's $t$ test, comparing mean values over the periods indicated.

In situ hybridization. One hour after tetanic stimulation, brains were removed, frozen on dry ice, and stored at $-70^{\circ} \mathrm{C}$. Sections $(14 \mu \mathrm{m})$ were cut on a cryostat and mounted on poly-L-lysine-coated glass slides and stored at $-70^{\circ} \mathrm{C}$. In situ hybridization was performed essentially as described by Jones et al. (2001). Briefly, sections were thawed at room temperature, fixed in $4 \%$ paraformaldehyde, acetylated in $1.4 \%$ triethanolamine and $0.25 \%$ acetic anhydride, dehydrated through graded ethanol solutions, and delipidated in chloroform. Sections were hybridized overnight at $42^{\circ} \mathrm{C}$ in $100 \mu \mathrm{l}$ of buffer containing $50 \%$ formamide, $4 \times \mathrm{SSC}$, $10 \%$ dextran sulfate, $5 \times$ Denhardt's solution, $200 \mu \mathrm{g} / \mathrm{ml}$ acid alkali cleaved salmon testis DNA, $100 \mu \mathrm{g} / \mathrm{ml}$ long-chain polyadenylic acid, 25 mM sodium phosphate, $\mathrm{pH} 7.0,1 \mathrm{~mm}$ sodium pyrophosphate, and $10^{5}$ cpm radiolabeled probe $(\sim 1 \mathrm{ng} / \mathrm{ml})$ under Parafilm coverslips. Sections were washed in $150 \mathrm{~mm}$ sodium chlorate $/ 15 \mathrm{~mm}$ sodium citrate $(1 \times \mathrm{SSC})$ at room temperature, $1 \times \mathrm{SSC}$ at $55^{\circ} \mathrm{C}(30 \mathrm{~min})$, and $0.1 \times \mathrm{SSC}$ at room temperature $(5 \mathrm{~min})$ and dehydrated in 70 and $95 \%$ ethanol. Sections were then exposed to autoradiographic film. $\left[{ }^{35} \mathrm{~S}\right] \mathrm{ATP}$ end-labeled probes (NEN, Boston, MA) were generated using terminal deoxynucleotidyl transferase (Promega, Madison, WI) according to the instructions of the manufacturer and purified over Sephadex G50 columns (Amersham Biosciences, Arlington Heights, IL). A 50-fold excess of unlabeled oligo was used as negative control. Autoradiographs were analyzed by measuring the integrated density relative to a ${ }^{14} \mathrm{C}$ standard using $\mathrm{NIH}$ Image software. Oligonucleotides of unique sequence were supplied by Oswel (Southampton, UK). Probe sequences were as follows: zif268, CCGTGGCTCAGCAGCATCATCTCCTCCAGTTTGGGGTAGTTGTCC, complementary to nucleotides coding for amino acids 2-16; Homer, GTCAGTTCCATCTTCTCCTGCGACTTCTCCTTTGCCAG, complementary to nucleotides coding for amino acids 111-123.

Primary cell cultures and transfection. Primary cultures were prepared according to Malgaroli and Tsien (1992), with minor modifications. Cells were plated at a density of 400,000 per well in six-well plates. Transfections were made with Lipofectamine (Invitrogen, San Diego, CA) or with modified $\mathrm{Ca}^{2+}$ phosphate $\left[2.5 \% \mathrm{CO}_{2}\right.$ during $2-3 \mathrm{hr}$ of transfection (Kohrmann et al., 1999)].

Cell culture and transfection. These were performed as described previously (Jones et al., 1995). Briefly, muscarinic acetylcholine receptor (mAChR), $\mathrm{M}_{1}$, and enhanced green fluorescent protein (EGFP)-ERKII were transiently expressed in COS-7 cells by electroporation using a Bio-Rad (Hercules, CA) Gene Pulser at $180 \mathrm{~V}$ and $960 \mu \mathrm{F}$ with $20 \mu \mathrm{g}$ of DNA- $0.4 \mathrm{~cm}$ cuvette $\left(4 \times 10^{-7}\right.$ cells, $\left.0.8 \mathrm{ml}\right)$.

MAPK assays. COS-7 cells or primary cortical neurons, which had been serum-starved overnight, were treated with the MEK inhibitor PD98059 or the tyrosine kinase inhibitor K252a and then stimulated with different compounds as specified in the text. After washing with
PBS $\left(\mathrm{Ca}^{2+}, \mathrm{Mg}^{2+}\right.$ free), activation was halted by the addition of lysis buffer [ $1 \%$ Triton X-100, $25 \mathrm{~mm}$ Tris, pH 7.5, $150 \mathrm{~mm}$ sodium chloride, $1 \mathrm{~mm}$ EDTA, $1 \mathrm{~mm}$ EGTA, pH 8.0, $20 \mathrm{~mm}$ sodium fluoride, $1 \mathrm{~mm}$ sodium pyrophosphate, $1 \mathrm{~mm}$ DTT, $2 \mu \mathrm{M}$ protein kinase A inhibitor, 1 mM sodium vanadate, and $0.5 \%$ protease inhibitor cocktail (Sigma, St. Louis, MO)]. Cells were removed from the wells using a rubber policeman and then centrifuged at $4^{\circ} \mathrm{C}$ in a microfuge at full speed for $15 \mathrm{~min}$ to remove insoluble components. Supernatants were added to an equal amount of sample buffer (40\% glycerol, $0.035 \%$ bromophenol blue, $15 \mathrm{~mm} \mathrm{DTT}$, and $2 \% \mathrm{SDS}$ ), snap frozen on dry ice, and stored at $-20^{\circ} \mathrm{C}$.

Western blot analysis. Aliquots in SDS sample buffer were subjected to SDS-PAGE (Laemmli, 1970; Schagger and von Jagow, 1987) and Western blot analysis (Burnette, 1981). After electrophoresis and electroblotting, the blots were blocked with $1 \%$ BSA or $5 \%$ dried milk for $1 \mathrm{hr}$ at room temperature. Blots were reacted with primary antibody either overnight in a cold room or for $1 \mathrm{hr}$ at room temperature. After three short washes, the blots were subsequently incubated for 1 $\mathrm{hr}$ at room temperature with HRP-linked protein A or protein G-HRP or HRP-conjugated anti-rabbit IgG or anti-mouse IgG (Amersham Biosciences). The blots were then exposed to ECL substrate and film (Amersham Biosciences). The primary antibodies used were Zif268 (1:500; Santa Cruz Biotechnology, Santa Cruz, CA), dually phosphorylated ERKI/II (dpERKI/II) [1:30,000 (Promega); 1:5000 (New England Biolabs, Beverly, MA)], and ERKI/II (1:2000; New England Biolabs). Usually, the blots were first treated with anti-dpERKI/II antibody, stripped with stripping buffer (100 mM $\beta$-mercaptoethanol, $2 \%$ SDS, and $62.5 \mathrm{~mm}$ Tris- $\mathrm{HCl}, \mathrm{pH} 6.7)$, and reprobed with antiERKI/II antibody.

RNA isolation and Northern blot analysis. Serum-deprived cortical cultures (12-14 d) were preincubated with or without PD98059 $(38 \mu \mathrm{M})$ for $20 \mathrm{~min}$. The cells were then stimulated for $30 \mathrm{~min}$ with BDNF (50 $\mathrm{ng} / \mathrm{ml}$ ) in the presence or absence of PD989059. Corresponding control cells were incubated with vehicle carrier (water or DMSO). After stimulation, the culture media was rapidly removed, and the cells were lysed in $500 \mu \mathrm{l}$ of Trizol reagent (Invitrogen). Total cellular RNA was isolated according to the recommendations of the manufacturer. The RNA (5-6 $\mu \mathrm{g})$ was fractionated in formaldehyde-containing gels and transferred onto nitrocellulose membranes (Hybond-N; Amersham Biosciences) as described. Prepared blots were hybridized to a DNA fragment encoding exon1 of the mouse zif268 gene. DNA probes were labeled with $\left[{ }^{32} \mathrm{P}\right] \mathrm{dCTP}$ using the Amersham Biosciences multiprime labeling system. To ensure the equivalent loading in each lane of all gels, Northern blots were reprobed with a 400 bp DNA fragment (coding region) of the mouse $\beta$-actin gene.

Preparation of plasmid. Rat ERKII in pcDNA plasmid was amplified by PCR and cloned into the multiple cloning site (BglII and SalI) of pEGFP-C1 (Clontech, Cambridge, UK) to give EGFP-ERKII (see Fig. 4). Kinase-dead or nonactivated EGFP-ERKII mutants were constructed by point mutations of lysine- 52 to alanine, threonine-183 to alanine, and tyrosine- 185 to phenylalanine, respectively, using sitedirected mutagenesis (Quickchange; Stratagene, La Jolla, CA).

Image acquisition and deconvolution. Images were recorded with a cooled CCD camera [model CH350L (PhotoMetrics, Huntington Beach, CA); sensor, model KAF1400 (Eastman Kodak, Rochester, NY); $1317 \times$ $10^{-35}$ pixels] using an Olympus Optical (Tokyo, Japan) IX70 inverted microscope and an Olympus U-Plan-Apo 100× objective (numerical aperture, 1.35). An EGFP filter (excitation, S490/20; emission, S528/38) and a rhodamine filter (excitation, S555/28; emission, S617/73) or DAPI filter (excitation, 360; emission, 457; Chroma Technology, Brattleboro, VT) were used. Typically, between 20 and 25 optical sections through focus ( $\mathrm{Z}$ step, $0.2 \mu \mathrm{m}$ ) were taken for each image. High-magnification epifluorescence images were deconvolved using Deltavision software (Applied Precision, Seattle, WA), on a SiGraphics computer, usually with 15 iterations, and processed in Adobe Photoshop Adobe Systems, San Jose, CA. Images of living cells in the submerged chamber were recorded at room temperature using the system described above with a change of objective to Olympus U-plan-Apo $40 \times$ (numerical aperture, 0.6). The primary cortical cultures were perfused with oxygenated ACSF (in mM: $120 \mathrm{NaCl}, 3 \mathrm{KCl}, 2 \mathrm{MgCl}_{2}, 2 \mathrm{CaCl}_{2}, 1.2 \mathrm{NaH}_{2} \mathrm{PO}_{4}, 23 \mathrm{NaHCO}_{3}$, and 11 glucose), and recording started $1 \mathrm{hr}$ after perfusion began. BDNF (50 $\mathrm{ng} / \mathrm{ml}$ ) was added at the indicated time points. 

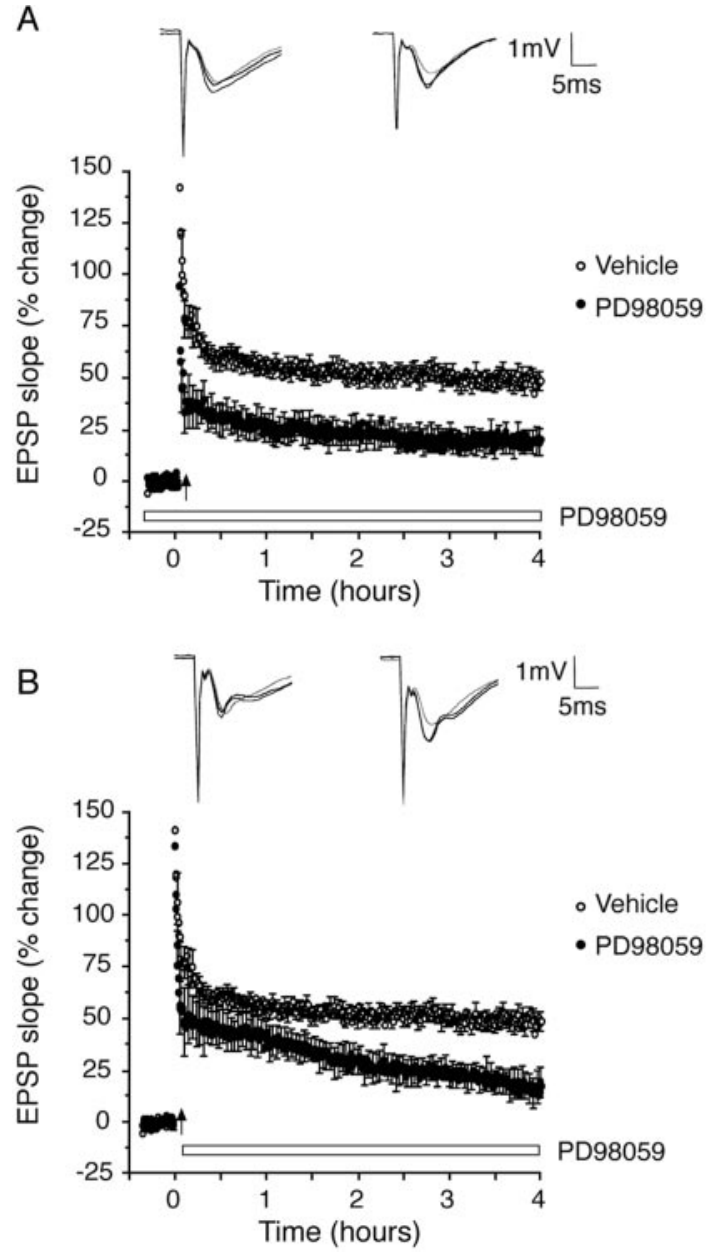

\section{RESULTS}

ERKI/II is required for full expression of both earlyand late-phase LTP in area CA1 of the hippocampus

Previous in vitro and in vivo studies have shown that inhibitors of ERKI/II activity attenuate the initial, as well as subsequent, levels of LTP obtained by tetanic stimulation (English and Sweat, 1997; Rosenblum et al., 2000). In these studies, the expression of LTP was followed for $60-90 \mathrm{~min}$. This time period is insufficient to determine whether the effect is confined to early LTP or whether late LTP is also blocked, because the duration of early LTP is $2-4 \mathrm{hr}$ as defined by sensitivity to translation inhibitors (Frey et al., 1988; Otani and Abraham, 1989). Moreover, the attenuation reported 60-90 min after induction may simply be a reflection of the lower initial levels of expression that is often seen in the presence of ERKI/II inhibitors (English and Sweatt, 1997). To further examine the roles of ERKI/II in early and late plasticity, we recorded the fEPSP for at least $4 \mathrm{hr}$ after tetanus and applied the drug either $40 \mathrm{~min}$ before or immediately after the tetanus. After the tetanus (six trains of 20 pulses at $100 \mathrm{~Hz}$ ), the initial potentiation showed a period of rapid decline (shortterm potentiation) (Bliss and Collingridge, 1993), which gave way after 20-30 min to a stable enhancement of the fEPSP slope lasting for at least $4 \mathrm{hr}$ (Fig. 1A,B, open circles). In slices exposed to PD98059 $(38 \mu \mathrm{M}) 40 \mathrm{~min}$ before induction of LTP, there was a significant reduction in potentiation $20 \mathrm{~min}$ after tetanus $(32.2 \pm$ $8.5 \%$ in the PD98059-treated group compared with $62.4 \pm 4.9 \%$
C

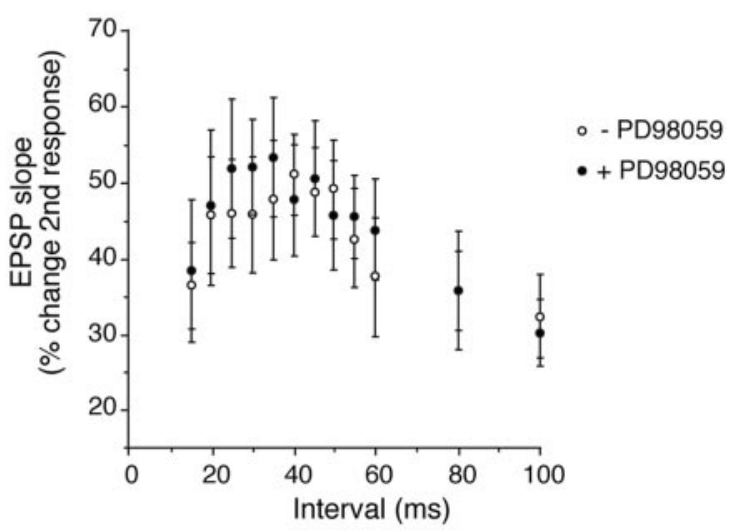

Figure 1. The MEK inhibitor PD98059 attenuates both early- and latephase LTP in area CA1 in vitro. A, Pretreatment of hippocampal slices for 45 min with PD98059 $(38 \mu \mathrm{M})$ impairs the induction of LTP and attenuates both early and late phases of maintenance $(n=8)$. $B$, PD98059 $(38 \mu \mathrm{M})$ applied immediately after induction of LTP impairs late-phase LTP $(n=$ 8 ). Same control group as in $A$. $C$, Pretreatment of hippocampal slices for 45 min does not affect paired-pulse facilitation in area CA1 $(n=5)$.

in control slices; $p<0.01)$. This result is in accordance with previous reports in which an MEK inhibitor was applied before potentiation, both in vivo and in the slice preparation (English and Sweatt, 1997; Rosenblum et al., 2000). Potentiation in the drug-treated slices declined slowly over the following $4 \mathrm{hr}$ [the increase in fEPSP slope measured $60 \mathrm{~min}$ after the tetanus was $26.0 \pm 7.1 \%$ compared with $54.5 \pm 4.2 \%$ in the control group $(p<0.005)$; 240 min after induction, the equivalent values were $18.7 \pm 6.3 \%$ compared with $48.3 \pm 4.7 \%(p<0.005)]$ (Fig. $1 A)$. In the second experiment, we avoided the complication of the difference in initial values of potentiation by perfusing PD98059 $(38 \mu \mathrm{M})$ immediately $(2 \mathrm{~min})$ after the tetanus. There were no significant differences between the control and the drug-treated slices 20 or 60 min after induction $[62.2 \pm 4.9$ vs $44.8 \pm 11 \%$, respectively, at 20 $\min (p>0.05) ; 54.7 \pm 4.2$ vs $41.6 \pm 7.0 \%$ at $60 \min (p>0.05)]$, but potentiation was significantly greater in control than in drugtreated slices when measured 240 min after induction (48.6 $\pm 4.6 \mathrm{vs}$ $18.5 \pm 6.3 \%$, respectively; $p<0.005$ ) (Fig. $1 B$ ). Application of PD98059 affected neither paired-pulse facilitation (Fig. 1C) nor basal synaptic transmission in the control pathway of any experiment (20 min after the tetanus to the potentiated pathway in the experiments illustrated in Fig. 1, $A$ and $B$, the change in the fEPSP slope in the control pathway was $1.7 \pm 0.7 \%$ in nontreated slices, $1.2 \pm 1.0 \%$ in slices treated for 60 min with PD98059, and $1.4 \pm$ $1.5 \%$ for slices treated for 18 min with PD98059; $n=8$ in each case). We conclude that ERKI/II has multiple effects on tetanus- 


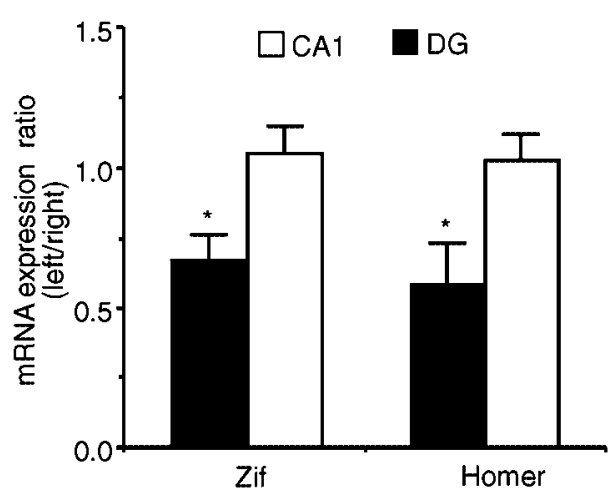

Figure 2. Expression of Zif268 and Homer mRNA 30 min after the induction of LTP in the dentate gyrus $(D G)$ in vivo is attenuated by the MEK inhibitor PD98059. Group data for three experiments in which mRNA for Homer and Zif268 was measured by in situ hybridization. PD98059 $(1 \mu \mathrm{l}, 38 \mu \mathrm{M})$ was microinjected over $10 \mathrm{~min}$ into the left hemisphere, and a similar volume of saline containing $0.2 \%$ DMSO was injected into the right hemisphere in each case. LTP was reduced in magnitude in the side injected with PD98059 (for group LTP data, see Rosenblum et al., 2000, their Fig. 1). The ratio of mRNA expression in the left and right sides was calculated from densitometric values obtained from sample fields in the dentate gyrus and area CA1. In the dentate gyrus, a significant reduction in the expression of both Zif268 and Homer was seen in the side injected with PD98059. There was no change in area CA1.

induced potentiation: it contributes to the level of potentiation that is achieved immediately after induction and is required for the full expression of both early and late LTP.

\section{ERKI/II activation is required for the tetanus-induced increase in expression of immediate early genes in the dentate gyrus in vivo}

LTP in the dentate gyrus of the hippocampus is associated with upregulation of the expression of mRNAs for immediate early genes, such as Zif268 (Cole et al., 1989; Wisden et al., 1990) and Homer (Roberts et al., 1996). To further explore the involvement of ERKI/II in the transcription of immediate early genes in neurons, we used in situ hybridization to compare the effect of the MEK inhibitor PD98059 on the expression of Zif268 and Homer mRNA in the hippocampus after tetanic stimulation. In experiments in which tetanic stimulation was delivered bilaterally to the perforant path, we showed previously that a unilateral injection of PD98059 into the hippocampus significantly attenuates LTP in the dentate gyrus on the injected side (Rosenblum et al., 2000). Here we adopted a similar experimental design to show that the upregulation of Zif268 and Homer in LTP is also ERKI/II dependent. Thirty minutes after bilateral tetanization of the perforant path, there were significant differences in the expression of both Zif268 and Homer in the dentate gyrus on the side injected with PD98059 compared with the potentiated control side [0.58 \pm $0.15(p<0.02)$ and $0.67 \pm 0.09(p<0.03)$ for Homer and Zif 268 , respectively, as measured by the ratio of the optical density for the two sides; $n=3$ ); no such differences were observed in area CA1 $(1.03 \pm 0.09$ and $1.06 \pm 0.11)$ (Fig. 2). These results extend the observations of Davis et al. (2000), in which intraperitoneal injection of MAP kinase inhibitors were shown to inhibit the tetanus-induced expression of Zif268. Intraperitoneal delivery of MAP kinase inhibitors may have systemic effects that contribute to gene transcription and does not localize the relevant ERKI/II activity to a specific brain area. In the present studies, PD98059 was delivered locally to the brain region of interest, and, in addition, we extend the range of the transcriptional response to include the IEG Homer.

\section{BDNF induces ERKI/II-dependent Zif}

There are now several lines of evidence implicating BDNF as a critical signaling molecule in the generation of late-phase LTP. Mice with a deleted BDNF gene or conditional deletion of the TrkB receptor are impaired in the generation of late-phase LTP (Korte et al., 1998; Minichiello et al., 1999). Similar results have been obtained with inhibitors of BDNF signaling, using functionblocking antibodies or BDNF-scavenging molecules (Schuman, 1999). Moreover, ERKI/II activation is both necessary for and correlated with LTP induced by BDNF application to the dentate gyrus in vivo (Ying et al., 2002). Delivery of exogenous BDNF leads to a slowly developing, persistent potentiation of synaptic transmission in the CA1 region of hippocampal slices and in the dentate gyrus in vivo (Kang and Schuman, 1996; Messaoudi et al., 1998; Schuman, 1999). BDNF-induced LTP is abolished by protein synthesis inhibitors (Kang and Schuman, 1996), and expression of BDNF-LTP is occluded after establishment of late-phase, but not early-phase, tetanus-induced LTP in area CA1 in vitro (Korte et al., 1998) and in the dentate gyrus in vivo (Messaoudi et al., 2000). Moreover, BDNF can induce strong ERKI/II activation in neurons (Pizzorusso et al., 2000). Does BDNF also induce Zif268 in cultured neurons, and, if so, is activation of ERKI/II a necessary step in the signaling pathway? To address these questions, we first determined the time and dose dependence of the activation of ERKI/II by BDNF in our cultures (Fig. 3A,B). BDNF, as well as carbachol (Auerbach and Segal, 1996) and tetraethylammonium (TEA) (Hanse and Gustafsson, 1994) can all induce LTP, and all induce a similar time-dependent increase in ERKI/II activation, peaking at $\sim 30 \mathrm{~min}$ (for BDNF, see Fig. $3 A$; similar results were obtained for carbachol and TEA, data not shown). The concentration dependence of the activation of ERKI/II by BDNF is illustrated in Figure $3 B$, which shows that BDNF was effective at a concentration as low as $10 \mathrm{ng} / \mathrm{ml}$. When applied at $50 \mathrm{ng} / \mathrm{ml}, \mathrm{BDNF}$ led to a robust activation of ERKI/II (Fig. $3 B$ ) that was attenuated by the tyrosine kinase inhibitor $\mathrm{K} 252 \mathrm{a}(0.5 \mu \mathrm{M})$ and blocked by $1 \mu \mathrm{M} \mathrm{K} 252 \mathrm{a}$ (Fig. $3 C)$. This result suggests that TrkB, which is a tyrosine kinase receptor, mediates ERKI/II activation by BDNF.

We next showed that application of BDNF leads to an increase in Zif268 mRNA and protein levels in neurons. In primary cortical cultures, $50 \mathrm{ng} / \mathrm{ml}$ BDNF induces Zif $268 \mathrm{mRNA}$ to a similar extent as 10\% serum. Moreover, PD98059 (38 $\mu \mathrm{M})$ attenuated the expression of Zif $268 \mathrm{mRNA}$, whereas the vehicle itself had no effect (Fig. 3D). We also analyzed the levels of Zif268 protein after BDNF with and without $38 \mu \mathrm{M}$ PD98059 and found that Zif268 protein levels were similarly increased by BDNF in an ERKI/IIdependent manner (Fig. 3E). Thus, activation of ERKI/II is a necessary step in the upregulation of Zif268 by BDNF.

\section{BDNF induces EGFP-ERKII nuclear translocation in neurons}

In PC12 cells, ERKI/II has been shown to translocate to the nucleus after prolonged activation, in which it regulates gene induction by activation of nuclear proteins, such as cAMP response element-binding protein (CREB) and Elk-1 (Impey et al., 1998; Brunet et al., 1999; Fanger, 1999). We wanted to determine whether a similar mechanism functioned in postmitotic neurons. To visualize ERKII translocation from one cellular compartment to another, we constructed a reporter protein consisting of EGFP 

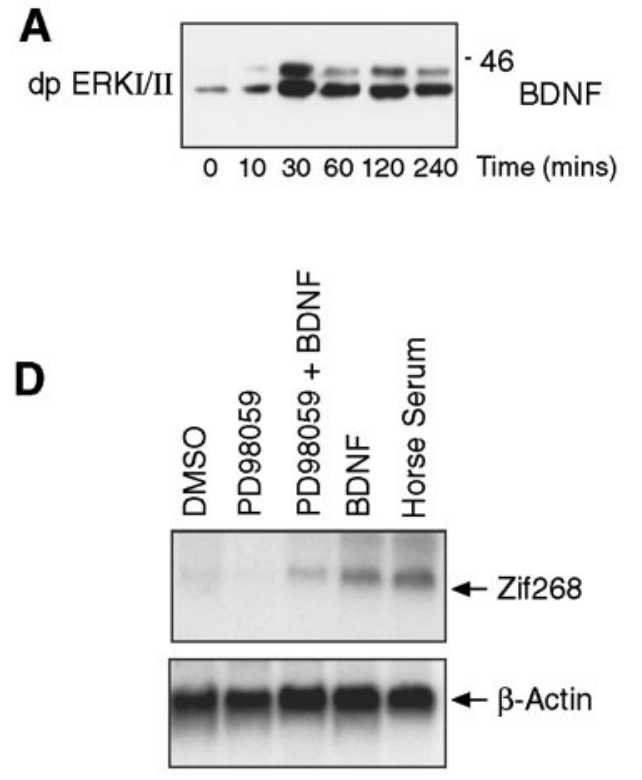
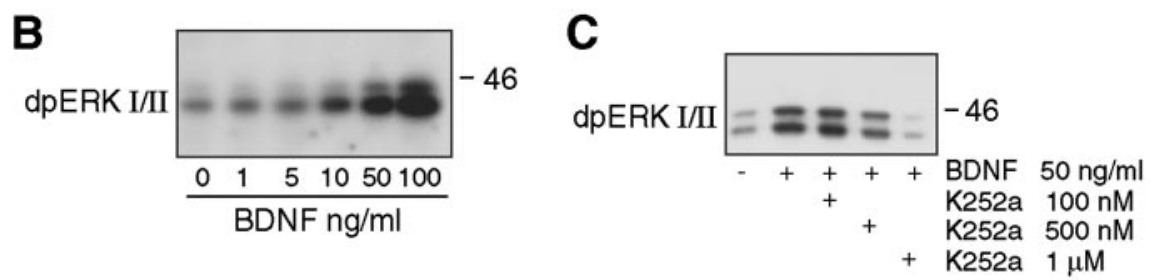

E

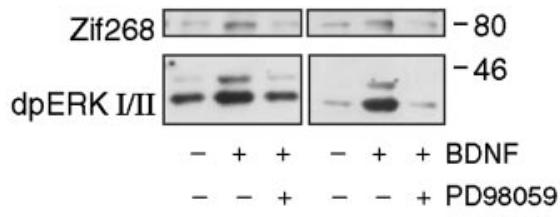

Figure 3. BDNF induces ERKI/II-dependent activation of Zif268 in primary cortical culture. A, Immunoblot showing the time dependence of activation (dual phosphorylation) of ERKI/II by BDNF $(50 \mathrm{ng} / \mathrm{ml})$ in cortical neurons maintained in culture. The concentration of dpERKI (44 $\mathrm{kDa}$ ) and dpERKII (42 kDa) reaches a peak between 10 and 60 min after application of BDNF. This blot and those in the other panels are representatives of three independent experiments. $B$, Dose dependency of ERKI/II activation by BDNF, measured 30 min after treatment. $C$, Dose-dependent effect of the tyrosine kinase inhibitor K252a on ERKI/II activation by BDNF (50 ng/ml). D, Northern blot analysis of Zif268 mRNA expression after stimulation with horse serum $(10 \%)$ or BDNF (50 ng/ml for $30 \mathrm{~min})$. Pretreatment with PD98059 (38 $\mu \mathrm{M})$, but not vehicle (0.33\% DMSO in media), attenuated BDNF-induced Zif268 mRNA expression. None of the treatments affected the level of $\beta$-actin. $E$, Western blot analysis of changes in Zif268 and dpERKI/II protein levels in cultured cortical cells after stimulation with BDNF (50 ng/ml). The BDNF-induced increases in Zif268 protein and in activated ERKI/II were both reduced by PD98059.

fused to ERKII (Fig. 4A). A series of control experiments was designed to establish that the recombinant EGFP-ERKII fusion protein was regulated and functioned in the same way as the endogenous enzyme.

ERKII is activated after dual phosphorylation by MEK on residues threonine-183 and tyrosine-185 (Seger and Krebs, 1995). We engineered a nonactivatable mutation of ERKII by sitedirected mutagenesis ("phosphorylation site mutant;" residues 183:threonine $\rightarrow$ arginine and 185:tyrosine $\rightarrow$ phenylalanine) (Fig. 4A). A second mutant EGFP-ERKII protein ("kinase-dead mutant") was generated by replacing lysine-52 by alanine, thus preventing the binding of ATP and rendering the protein kinase domain inactive (Robinson et al., 1996) (Fig. 4A). To assess the response of these constructs relative to endogenous ERKII, we transiently expressed them in COS-7 cells overexpressing the $\mathrm{M}_{1}$ subtype of muscarinic receptor ( $\mathrm{mAChR}$ ). We showed previously that stimulation of these transiently transfected cells by the mAChR agonist carbachol leads to a strong and prolonged activation of ERKI/II (Rosenblum et al., 2000). Carbachol (100 $\mu \mathrm{M})$ induced a time-dependent phosphorylation of the wild type EGFP-ERKII and of the kinase-dead mutant in a similar manner to endogenous ERKII but had no effect on the phosphorylation site mutant (Fig. 4B). The time course of carbachol induction of the EGFP-ERKII fusion proteins is comparable with that of the endogenous enzyme in COS-7, HEK 293, and PC12 cells (Fig. 4 and data not shown).

The best characterized example of activity-dependent translocation of ERKI/II to the nucleus occurs in PC12 cells stimulated to differentiate with NGF (Marshall, 1995). We established stably transfected PC12 cell lines expressing EGFP-ERKII. In unstimulated cells, EGFP-ERKII was mainly found in the cytoplasm. Treatment of the PC12 cells with $50 \mathrm{ng} / \mathrm{ml} \mathrm{NGF}$ for $4 \mathrm{hr}$, a dose sufficient to cause differentiation, induced nuclear translocation of both the EGFP-ERKII and kinase-dead EGFP-ERKII and, to a lesser extent, the phosphorylation site mutant EGFP-ERKII (Fig. $5 A$ ). The PC12 cells had fully differentiated a few days after NGF treatment, and, by this time, the different constructs had diff used throughout the entire cell (Fig. 5A). We showed that application of BDNF leads to ERKI/II-dependent Zif268 expression in cortical cultures (Fig. 3), and NGF can induce ERKI/II-dependent Zif268 expression in PC12 cells (Kumahara et al., 1999). We therefore analyzed Zif268 expression in PC12 cells stably expressing EGFP-ERKII before and $4 \mathrm{hr}$ after treatment with NGF. As expected, cells stimulated with NGF showed both EGFP-ERKII nuclear localization and Zif268 expression (Fig. 5B).

BDNF induces ERKI/II-dependent LTP in the dentate gyrus in vivo (Ying et al., 2002), and we showed that the BDNF-induced expression of Zif268 in cultured cortical neurons is ERKI/II dependent (Fig. 3D). To determine whether ERKI/II translocates to the nucleus after application of BDNF, we expressed EGFP-ERKII in primary cortical cultures. EGFP-ERKII has a cytoplasmic distribution in unstimulated glial and neuronal cells (Fig. 6A,B). One hour after incubation with BDNF $(50 \mathrm{ng} / \mathrm{ml})$, the distribution remained cytoplasmic. However, after incubation for 2-4 hr, EGFP-ERKII in neurons showed clear evidence of nuclear accumulation, whereas in glia its distribution remained mainly cytoplasmic (Fig. 6A). The images presented in Figures 5 and $6 A$ were obtained from fixed tissue. A similar time course of translocation from cytoplasm to nucleus was also seen in living neurons imaged for $4-5 \mathrm{hr}$ after application of BDNF (Fig. $6 B$ ).

\section{DISCUSSION}

In the present study, we show that ERKI/II is involved in both early- and late-phase hippocampal LTP. We did not detect any 
A

(1) GFP-ERK2

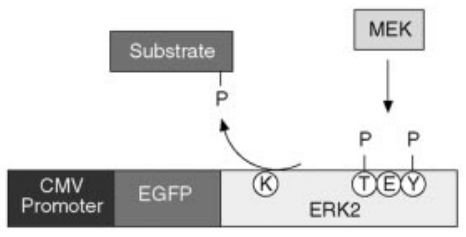

(2) GFP-ERK2 Kinase dead mutant $\mathrm{K}^{52} \rightarrow \mathrm{A}^{52} \quad$ (ERK2 is unable to phosphorylate substrates)

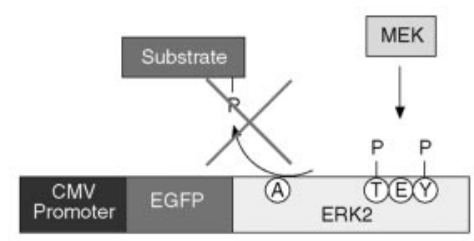

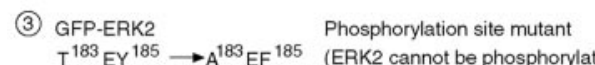
$\mathrm{T}^{183} \mathrm{EY}^{185} \rightarrow \mathrm{A}^{183} \mathrm{EF}^{185}$ (ERK2 cannot be phosphorylated
activated by MEK)

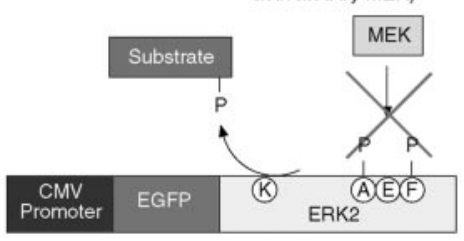

B

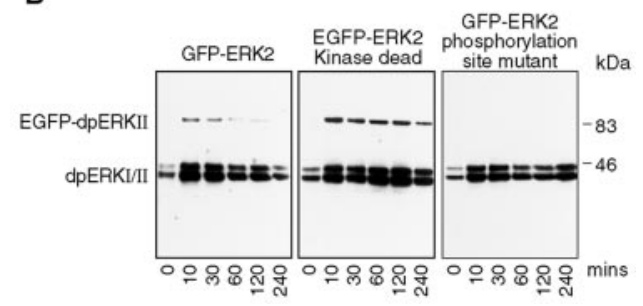

Figure 4. Design of EGFP-linked ERKII constructs to visualize cellular redistribution of ERKI/II. $A$, Three constructs were engineered: EGFPERKII, EGFP-ERKII with a mutation in the ATP binding site that abolishes kinase activity [kinase-dead mutant $(K D)$ ], and EGFP-ERKII with a mutated MEK phosphorylation site, rendering the protein inactivatable by MEK. $B$, Immunoblots showing activated ERKI/II in COS-7 cells overexpressing the $\mathrm{M}_{1} \mathrm{mAChR}$, stimulated with carbachol $(100 \mu \mathrm{M})$. The blots demonstrate that the time dependence of activation of normal and kinase-dead EGFP-ERKII (left and middle panels; the expected molecular weight of EGFP-dpERKII is $78 \mathrm{kDa}$ ) is similar to that of endogenous ERKI/II (Fig. $3 A$ ). The phosphorylation site mutant (right panel) remains unphosphorylated. The blots are representative of three different experiments. $C M V$, Cytomegalovirus.

effect of the MEK kinase inhibitor PD98059 on baseline responses or on the development of potentiation of the fEPSP during tetanic stimulation, although Winder et al. (1999) reported that the MEK inhibitor U0126 reduces cell firing during $5 \mathrm{~Hz}$ stimulation in area CA1. Nevertheless, in slices treated with PD98059 before the induction of LTP, there was a detectable effect on potentiation within 2 min of tetanization. One possibility is that ERKI/II rapidly modulates, directly or indirectly, the function of postsynaptic ion channels, such as AMPA receptors or potassium channels (Fig. 7) (Adams et al., 2000). Another
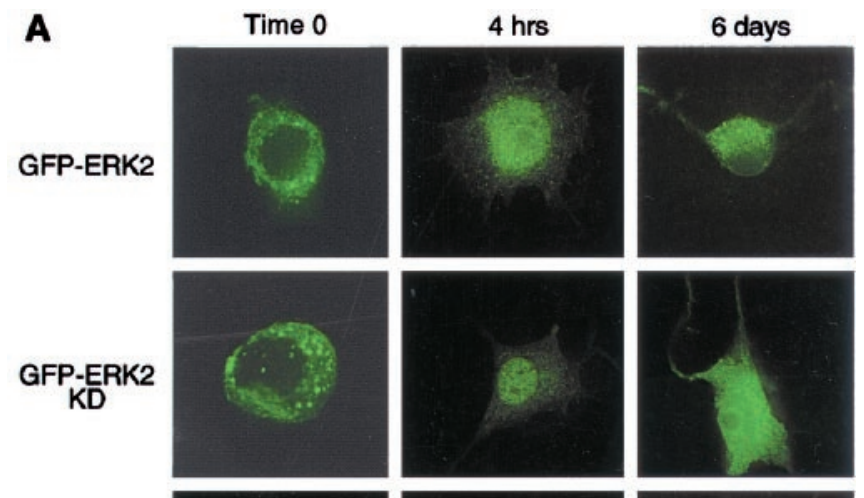

$\underset{\text { PS }}{\text { GFP-ERK2 }}$
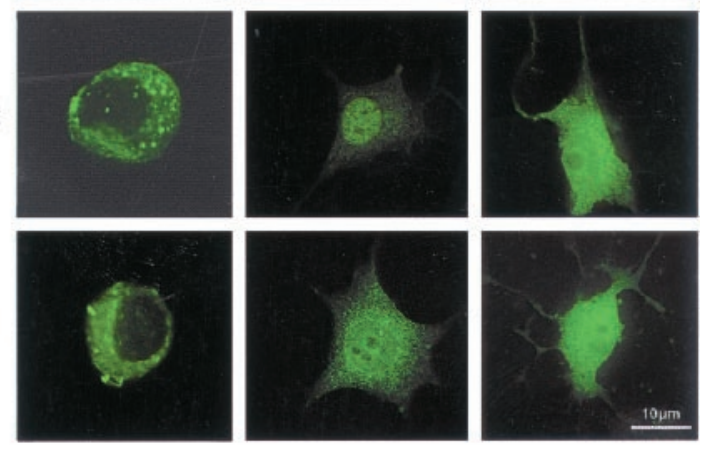

B

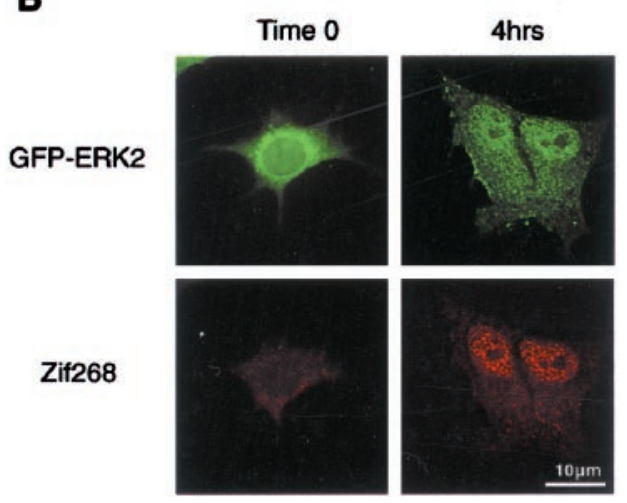

Figure 5. NGF induces nuclear translocation of EGFP-ERKII and Zif268 expression in PC12 cells stably expressing EGFP-ERKII. $A, \mathrm{PC} 12$ cells stably expressing EGFP-ERKII, the kinase-dead $(K D)$ mutant EGFPERKII, or the EGFP-ERKII phosphorylation site $(P S)$ mutant were serum-starved overnight and then incubated with NGF for $4 \mathrm{hr}$ or $6 \mathrm{~d}(50$ $\mathrm{ng} / \mathrm{ml})$. Representative cells from each treatment $(n=3)$ are displayed. In unstimulated cells, the distribution of the EGFP-ERKII constructs was mainly cytoplasmic. Four hours after exposure to NGF, cells transfected with EGFP-ERKII or kinase-dead EGFP-ERKII showed evidence of nuclear translocation; in cells transfected with the phosphorylation site mutant EGFP-ERKII, nuclear translocation was less pronounced. By $6 \mathrm{~d}$, after the cells had become fully differentiated, all three constructs were evenly distributed throughout the cell. $B$, PC12 cells stably expressing EGFP-ERKII were incubated with NGF for $4 \mathrm{hr}$ and stained for Zif268 protein. Representative cells are shown, which demonstrate cytosolic expression of EGFP-ERKII and very low levels of Zif268 before stimulation. Four hours after treatment with NGF $(50 \mathrm{ng} / \mathrm{ml})$, nuclear expression of both EGFP-ERKII and Zif268 protein is clearly evident.

possibility is modulation of release mechanisms, for example, via phosphorylation of synapsin1 (Jovanovic et al., 2000), although the lack of effect of PD98059 on paired-pulse facilitation argues against a presynaptic action of ERKI/II (Fig. 1C). When PD98509 was given immediately after the induction of LTP, the time course of decay was similar to that observed with a similar tetanus protocol $(20$ stimuli at $100 \mathrm{~Hz}$, repeated six times at $3 \mathrm{sec}$ intervals) in the presence of protein synthesis inhibitors in area CA1 of mouse hippocampal slices (K. Bradshaw, N. J. Emptage, and T. V. P. Bliss, unpublished observation). A similar time course was observed by Patterson et al. (2001), after theta-burst 
A
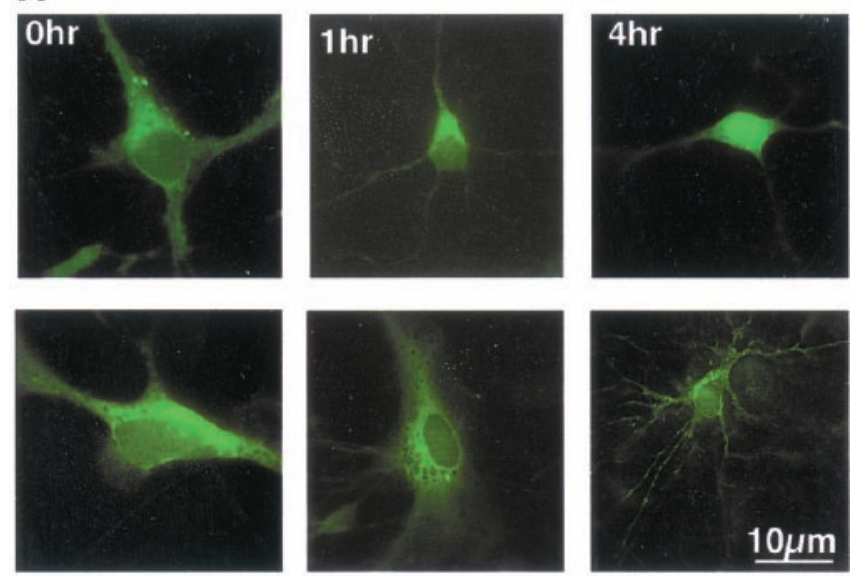

B
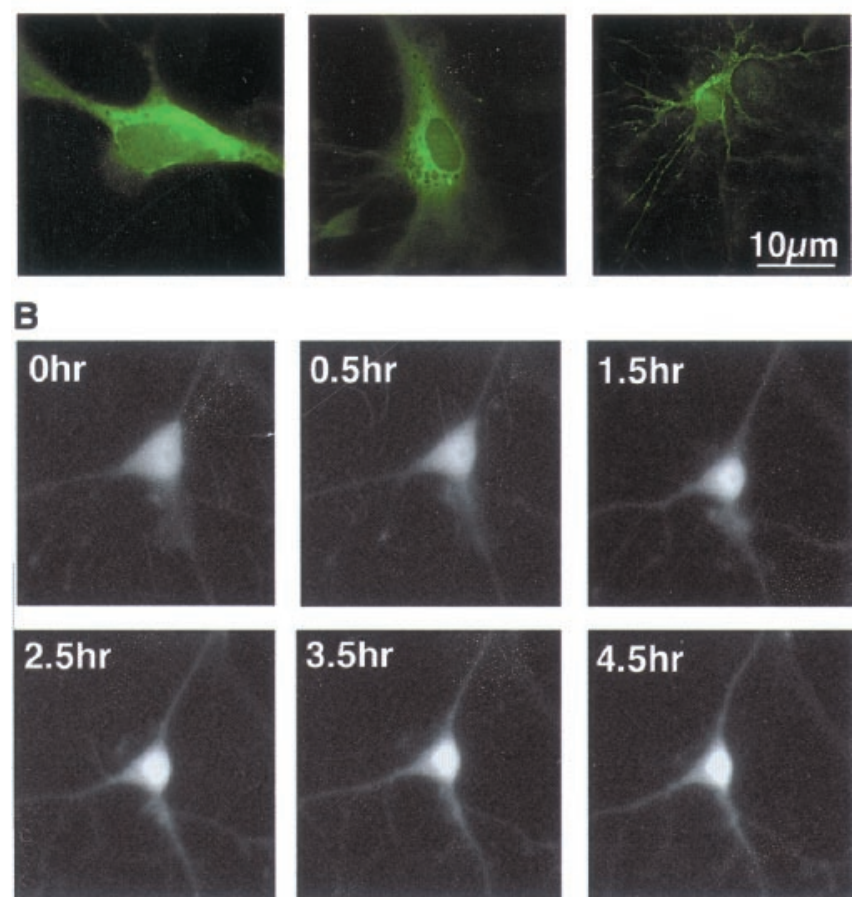

Figure 6. BDNF induces nuclear translocation of EGFP-ERKII in neurons and glia in primary cortical cultures. $A$, Neurons (top row) and glia (bottom row) expressing EGFP-ERKII before (0 hr), $1 \mathrm{hr}$, and $4 \mathrm{hr}$ after incubation in BDNF $(50 \mathrm{ng} / \mathrm{ml}$; representative of $n=3$ in each case). At $4 \mathrm{hr}$, distribution in glial cells remained cytosolic, whereas most neurons showed a strong nuclear signal. Cells were fixed in $4 \%$ paraformaldehyde in PBS. $B$, Live cortical neuron imaged at intervals after incubation in BDNF (50 ng $/ \mathrm{ml}$; representative of $n=3)$. EFGP-ERKII fluorescence in the nucleus increased strongly 2-4 hr after the start of incubation.

stimulation in slices of mouse hippocampus exposed to the MEK inhibitor UO126. Our data reveal that, in addition to blocking a component of late LTP, activated ERKI/II is also required for a component of early LTP.

The role(s) of ERKI/II in long-lasting plasticity are likely to be mediated through its potential regulation of both translation [e.g., via regulation of ribosomal S6 kinase-2 (RSK2) or Mnk1/2] (Frodin and Gammeltoft, 1999) and transcription processes (Thomson et al., 1999) (Fig. 7). Here, using the MEK inhibitor PD98059, we show that tetanus-induced expression of mRNA encoding the transcription factor Zif268 is dependent on activation of ERKI/II (Fig. 2). Another model of hippocampal synaptic plasticity is the persistent potentiation produced by application of BDNF (Kang and Schuman, 1995; Messaoudi et al., 1998); in this case, also, potentiation requires activation of ERKI/II (Ying et al., 2002). In this paper, we demonstrated that BDNF activates ERKI/II and induces ERKI/II-dependent expression of Zif268 mRNA and protein in cortical primary cultures (Fig. 3). In other cell types, regulation of transcription by ERKI/II involves its nuclear translocation (Boglari et al., 1998; Brunet et al., 1999). If

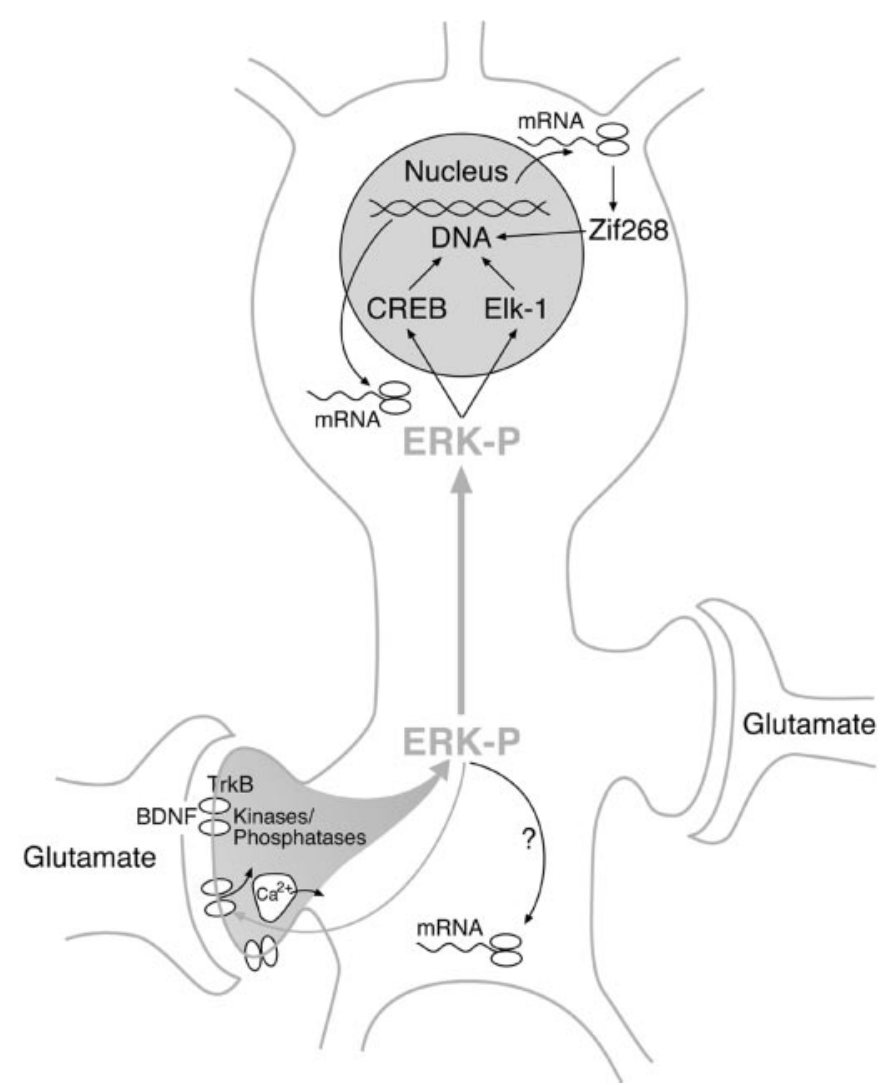

Figure 7. The role of ERKI/II in short- and long-term synaptic plasticity. ERKI/II are both highly expressed in the soma and processes of fully differentiated neurons in the CNS (Ortiz et al., 1995). Two lines of evidence suggest that the ERKI/II actions can be targeted either dendritically or somatically. First, PD98059 had no effect on paired-pulse facilitation but affected potentiation immediately after induction (Fig. 1), indicating a dendritic location in the basal state, and immediately after induction. Second, ERKI/II-dependent gene expression was detected in the granule cells of the dentate gyrus after tetanic stimulation of the perforant path in vivo (Fig. 2). The short-term effect of PD98059 may be dependent on differential sensitivity of different neurons to the drug (e.g., via regulation of local circuit inhibition) or to a direct modulation of ion channels involved in the expression of the potentiation (e.g., glutamate receptors). The long-term effect of ERKI/II may involve modulation of protein synthesis (e.g., by modulating glycogen synthase kinase or p90RSK) and/or transcription. Here we show that ERKI/II is necessary for immediate early gene transcription in neurons after LTP (Fig. 2) or BDNF stimulation (Fig. 4D) and that its effect on late-phase LTP is similar to that of protein synthesis inhibitors (Fig. 1). ERKI/II regulation of transcription is mediated by its translocation to the nucleus (Figs. 5, 6). In transformed cells, an unknown factor regulating ERKII nuclear localization is presumed to be abnormal. However, this is not the case in primary cultures in which prolonged stimulation can lead to its nuclear translocation (Fig. 6). In the nucleus, ERKI/II is known to phosphorylate nuclear proteins such as Elk-1, which in turn can modulate transcription (Hodge et al., 1998). Induction of transcription factors such as Zif268 can induce a second wave of transcriptional regulation. In this work, we describe one possible route of information flow from the synapse to the cell body; others may operate in parallel in certain conditions (e.g., via $\mathrm{Ca}^{2+}$ waves). The specificity of an input is determined by the synapse, whereas activation and translocation of ERKII can be caused by both synaptic and extrasynaptic stimulation. The mechanisms by which the modulated synapse recruits the newly synthesized proteins and stabilizes its modified connections over time remains unclear (Frey and Morris, 1998).

the modulation of gene expression by activated ERKI/II is important in the formation of late-phase LTP, a similar translocation to the nucleus would be expected to occur in neurons. To establish whether this is the case, we analyzed the effect of BDNF 
on the movement of EGFP-ERKII in neurons and other cells. BDNF induced a translocation of EGFP-ERKII to the nucleus in neurons (Fig. 6). Depolarization, $\mathrm{CA}^{2+}$ influx, and G-protein activation can also induce prolonged activation of ERKI/II (Rosenblum et al., 2000). The integration of these various signals is likely to modulate plasticity-dependent neuronal gene expression by determining the amount or duration of activation and the subsequent subcellular accumulation of ERKI/II (Fig. 7).

\section{Involvement of ERKI/II in late-phase LTP}

Inhibitors of protein synthesis and transcription are known to affect long-term but not short-term memory (Rosenblum et al., 1993; Houpt and Berlin, 1999). LTP shares this basic biochemical feature of learning and memory. Inhibition of protein synthesis, in vivo and in slices, inhibits late-phase but not short-phase LTP (Frey et al., 1988; Otani and Abraham, 1989), providing inhibitors are present during or immediately after LTP induction. Latephase LTP has been studied extensively in the CA1 region of the hippocampus in vitro (Frey and Morris, 1997). We thus used this system to study the effect of MEK inhibitors on the different phases of LTP. Moreover, MEK inhibitors specifically attenuate long- but not short-term memory in different brain areas subserving different learning paradigms (Berman et al., 1998). It has been reported by us and others that MEK inhibitors applied before tetanic stimulation can attenuate LTP within minutes of induction (English and Sweatt, 1997; Winder et al., 1999; Rosenblum et al., 2000). We monitored LTP for at least $4 \mathrm{hr}$ after tetanization and observed that PD98059 had two different time-dependent effects. First, the initial magnitude of LTP was reduced; second, the remaining potentiation decayed with a similar time course to that caused by inhibitors of protein synthesis (Fig. 1). Moreover, when PD98059 was applied immediately after LTP induction, the initial effect on the magnitude of LTP was not observed, and the long-term inhibitory effect was unaffected (Fig. $1 B$ ). These results suggest that postsynaptic ERKI/II-mediated modulation of protein synthesis is involved in the induction of late-phase LTP. In an invertebrate system, the Aplysia ERKI/II homolog is similarly required for long-term facilitation and translocates to the nucleus following protocols leading to long-term facilitation (Martin et al., 1997).

What genes are modulated via the ERKI/II pathway by plasticity-inducing stimulation? The expression of the immediate early genes Zif268 and Homer is upregulated after the induction of LTP in the dentate gyrus of the hippocampus (Wisden et al., 1990; Kato et al., 1997), and Zif268 is required for the expression of late-phase LTP and long-term memories (Jones et al., 2001). We therefore compared the induction of these mRNA species after tetanic stimulation of the perforant path in the presence of a MEK inhibitor. PD98059 attenuated the induction of both Zif268 and Homer compared with untreated controls (Fig. 2). These results confirm and extend recent results obtained by Davis et al. (2000) and together indicate that ERKI/II modulates latephase LTP and does so at least in part by modulating immediate early gene expression.

\section{BDNF induces ERKI/II-dependent Zif268 expression in primary cortical cultures}

BDNF can induce plasticity both during development and in the mature CNS (for review, see Jankowsky and Patterson, 1999). In the CA1 region of the hippocampal slice, BDNF induces latephase, protein synthesis-dependent LTP (Korte et al., 1998), although this may be dependent on the age of the animal
(Jankowsky and Patterson, 1999). In the dentate gyrus in vivo, late-phase LTP may be induced by tetanic stimulation or by BDNF infusion (Messaoudi et al., 1998; Patterson et al., 2001). The MEK inhibitor U0126 blocks BDNF-induced LTP and the associated increase in ERKI/II activation (Ying et al., 2002). Consistent with the idea that, after prolonged activation, ERKI/II can affect transcription, we find that the enhanced expression of Zif 268 mRNA and protein induced by BDNF in cultured neurons is ERKI/II dependent (Fig. $3 D, E$ ). These results suggest a model in which exogenous BDNF leads to the phosphorylation and translocation of ERKI/II to the nucleus in which it activates the upregulation of immediate early genes, including those encoding the transcription factor Zif268 and the cytoskeletal protein Homer (Fig. 7). These genes may be necessary, along with others, for the induction of persistent, late LTP. Indeed, antisense and knock-out studies have shown that both zif268 and another activity-related cytoskeletal gene, arc (also known as arg 3.1/BAD1) are required for the induction of persistent LTP in the dentate gyrus in vivo (Guzowski et al., 2000; Jones et al., 2001). A difficulty with this model is that Ying et al. (2002) found no detectable increase in Zif268 mRNA after BDNF-induced LTP in the dentate gyrus of the anesthetized animal, although there was a robust increase in levels of arc mRNA. This is in contrast to the rapid and reliable upregulation of Zif268 mRNA that occurs in granule cells of the dentate gyrus with tetanus-induced LTP (Cole et al., 1989; Wisden et al., 1990). It is likely therefore that, in the intact animal, there are different routes for the induction of persistent LTP involving different although overlapping sets of immediate early genes and effector genes.

\section{Visualization of the intracellular localization of EGFP-ERKII}

At least three factors are involved in the process of ERKI/II nuclear translocation: the amount of ERKI/II protein, its level of activation, and an additional protein mediator of nuclear localization (Ferrell, 1998). Thus, the threshold for ERKII nuclear translocation after its activation is different in different cells and is lower in transformed cells than in normal cells. We demonstrated that NGF stimulation causes nuclear translocation of EGFP-ERKII in a PC12 cell line stably expressing low levels of cytoplasmic EGFP-ERKII. Similarly, in neurons, BDNF induces translation of EGFP-ERKII to the nucleus (Fig. 6). Our demonstration that plasticity-inducing stimulation provokes nuclear translocation of ERKII provides a plausible mechanism for the increase in activated nuclear ERKI/II after the induction of LTP reported by Davis et al. (2000) and the trkB-dependent accumulation of phospho-ERKI/II in the nucleus described by Patterson et al. (2001). Together, these results strongly suggest that the increase in nuclear phospho-ERKI/II and the subsequent activation of the transcription factor Zif268 and other immediate early genes are consequences of either the direct translocation of phospho-ERKI/II to the nucleus or translocation of unphosphorylated ERKI/II and its subsequent phosphorylation by nuclear kinases. We note, finally, that visualization of nuclear EGFPERKII may provide a useful experimental tool for the identification of cells participating in long-term plasticity and memory circuits.

\section{REFERENCES}

Adams JP, Anderson AE, Varga AW, Dineley KT, Cook RG, Pfaffinger PJ, Sweatt JD (2000) The A-type potassium channel kv4.2 is a sub- 
strate for the mitogen-activated protein kinase ERK. J Neurochem 75:2277-2287.

Atkins CM, Selcher JC, Petraitis JJ, Trzaskos JM, Sweatt JD (1998) The MAPK cascade is required for mammalian associative learning. Nat Neurosci 1:602-609.

Auerbach JM, Segal M (1996) Muscarinic receptors mediating depression and long-term potentiation in rat hippocampus. J Physiol (Lond) 492:479-493.

Bailey CH, Kaang BK, Chen M, Martin KC, Lim CS, Casadio A, Kandel ER (1997) Mutation in the phosphorylation sites of MAP kinase blocks learning-related internalization of apCAM in Aplysia sensory neurons. Neuron 18:913-924.

Berman DE, Hazvi S, Rosenblum K, Seger R, Dudai Y (1998) Specific and differential activation of mitogen-activated protein kinase cascades by unfamiliar taste in the insular cortex of the behaving rat. J Neurosci 18:10037-10044.

Bliss TV, Collingridge GL (1993) A synaptic model of memory: longterm potentiation in the hippocampus. Nature 361:31-39.

Blum S, Moore AN, Adams F, Dash PK (1999) A mitogen-activated protein kinase cascade in the CA1/CA2 subfield of the dorsal hippocampus is essential for long-term spatial memory. J Neurosci 19:3535-3544

Boglari G, Erhardt P, Cooper GM, Szeberenyi J (1998) Intact Ras function is required for sustained activation and nuclear translocation of extracellular signal-regulated kinases in nerve growth factorstimulated PC12 cells. Eur J Cell Biol 75:54-58.

Brunet A, Roux D, Lenormand P, Dowd S, Keyse S, Pouyssegur J (1999) Nuclear translocation of p42/p44 mitogen-activated protein kinase is required for growth factor-induced gene expression and cell cycle entry. EMBO J 18:664-674.

Burnette WN (1981) "Western blotting": electrophoretic transfer of proteins from sodium dodecyl sulfate-polyacrylamide gels to unmodified nitrocellulose and radiographic detection with antibody and radioiodinated protein A. Anal Biochem 112:195-203.

Cole AJ, Saffen DW, Baraban JM, Worley PF (1989) Rapid increase of an immediate early gene messenger RNA in hippocampal neurons by synaptic NMDA receptor activation. Nature 340:474-476.

Crow T, Xue-Bian JJ, Siddiqi V, Kang Y, Neary JT (1998) Phosphorylation of mitogen-activated protein kinase by one-trial and multi-trial classical conditioning. J Neurosci 18:3480-3487.

Davis HP, Squire LR (1984) Protein synthesis and memory: a review. Psychol Bull 96:518-559.

Davis S, Vanhoutte P, Pages C, Caboche J, Laroche S (2000) The MAPK/ERK cascade targets both Elk-1 and cAMP response elementbinding protein to control long-term potentiation-dependent gene expression in the dentate gyrus in vivo. J Neurosci 20:4563-4572.

English JD, Sweatt JD (1997) A requirement for the mitogen-activated protein kinase cascade in hippocampal long term potentiation. J Biol Chem 272:19103-19106.

Fanger GR (1999) Regulation of the MAPK family members: role of subcellular localization and architectural organization. Histol Histopathol 14:887-894.

Ferrell JE (1998) How regulated protein translation can produce switchlike responses. Trends Biochem Sci 23:461-465.

Frey U, Morris RG (1997) Synaptic tagging and long-term potentiation. Nature 385:533-536.

Frey U, Morris RG (1998) Synaptic tagging: implications for late maintenance of hippocampal long-term potentiation. Trends Neurosci 21:181-188.

Frey U, Krug M, Reymann KG, Matthies H (1988) Anisomycin, an inhibitor of protein synthesis, blocks late phases of LTP phenomena in the hippocampal CA1 region in vitro. Brain Res 452:57-65.

Frodin M, Gammeltoft S (1999) Role and regulation of $90 \mathrm{kDa}$ ribosomal S6 kinase (RSK) in signal transduction. Mol Cell Endocrinol 151:65-77.

Guzowski JF, Lyford GL, Stevenson GD, Houston FP, McGaugh JL, Worley PF, Barnes CA (2000) Inhibition of activity-dependent arc protein expression in the rat hippocampus impairs the maintenance of long-term potentiation and the consolidation of long-term memory. J Neurosci 20:3993-4001.

Hanse E, Gustafsson B (1994) TEA elicits two distinct potentiations of synaptic transmission in the CA1 region of the hippocampal slice. J Neurosci 8:5028-5034.

Hodge C, Liao J, Stofega M, Guan K, Carter-Su C, Schwartz J (1998) Growth hormone stimulates phosphorylation and activation of elk-1 and expression of c-fos, egr-1, and junB through activation of extracellular signal-regulated kinases 1 and 2. J Biol Chem 273:31327-31336.

Houpt TA, Berlin R (1999) Rapid, labile, and protein synthesisindependent short-term memory in conditioned taste aversion. Learn Mem 6:37-46.

Impey S, Obrietan K, Wong ST, Poser S, Yano S, Wayman G, Deloulme JC, Chan G, Storm DR (1998) Cross talk between ERK, PKA is required for $\mathrm{Ca}^{2+}$ stimulation of CREB-dependent transcription and ERK nuclear translocation. Neuron 21:869-883.
Jankowsky JL, Patterson PH (1999) Cytokine and growth factor involvement in long-term potentiation. Mol Cell Neurosci 14:273-286.

Jones PG, Curtis CA, Hulme EC (1995) The function of a highlyconserved arginine residue in activation of the muscarinic M1 receptor. Eur J Pharmacol 288:251-257.

Jones MW, French PJ, Bliss TV, Rosenblum K (1999) Molecular mechanisms of long-term potentiation in the insular cortex in vivo. J Neurosci 19:RC36(1-8).

Jones MW, Errington ML, French PJ, Fine A, Bliss TVP, Garel S, Charnay P, Bozon B, Laroche S, Davis S (2000) A requirement for the immediate early gene Zif268 in the expression of late LTP, the consolidation of long-term memories. Nat Neurosci 4:289-296.

Jovanovic JN, Czernik AJ, Fienberg AA, Greengard P, Sihra TS (2000) Synapsins as mediators of BDNF-enhanced neurotransmitter release. Nat Neurosci 3:323-329.

Kang H, Schuman EM (1995) Long-lasting neurotrophin-induced enhancement of synaptic transmission in the adult hippocampus. Science 267:1658-1662.

Kang H, Schuman EM (1996) A requirement for local protein synthesis in neurotrophin-induced hippocampal synaptic plasticity. Science 273:1402-1406

Kato A, Ozawa F, Saitoh Y, Hirai K, Inokuchi K (1997) Vesl, a gene encoding VASP/Ena family related protein, is upregulated during seizure, long-term potentiation and synaptogenesis. FEBS Lett 412:183-189.

Kohrmann M, Haubensak W, Hemraj I, Kaether C, Lessmann VJ, Kiebler MA (1999) Fast, convenient, and effective method to transiently transfect primary hippocampal neurons. J Neurosci Res 58:831-835.

Korte M, Kang H, Bonhoeffer T, Schuman E (1998) A role for BDNF in the late phase of hippocampal long-term potentiation. Neuropharmacology 37:553-559.

Kumahara E, Ebihara T, Saffen D (1999) Nerve growth factor induces zif268 gene expression via MAPK-dependent and -independent pathways in PC12D cells. J Biochem 125:541-553.

Laemmli UK (1970) Cleavage of structural proteins during the assembly of the head of bacteriophage T. Nature 227:680-685.

Malgaroli A, Tsien RW (1992) Glutamate-induced long-term potentiation of the frequency of miniature synaptic currents in cultured hippocampal neurons. Nature 357:134-139.

Marshall CJ (1995) Specificity of receptor tyrosine kinase signaling: transient versus sustained extracellular signal-regulated kinase activation. Cell 80:179-185

Martin KC, Michael D, Rose JC, Barad M, Casadio A, Zhu H, Kandel ER (1997) MAP kinase translocates into the nucleus of the presynaptic cell and is required for long-term facilitation in Aplysia. Neuron 18:899-912.

Messaoudi E, Bardsen K, Srebro B, Bramham CR (1998) Acute intrahippocampal inf usion of BDNF induces lasting potentiation of synaptic ransmission in the rat dentate gyrus. J Neurophysiol 79:496-499.

Messaoudi E, Croll SD, Bramham CR (2000) Characterization of BDNF-induced long-term potentiation in the rat dentate gyrus. Soc Neurosci Abstr 26:247.

Minichiello L, Korte M, Wolfer D, Kuhn R, Unsicker K, Cestari V, Rossi-Arnaud C, Lipp HP, Bonhoeffer T, Klein R (1999) Essential role for TrkB receptors in hippocampus-mediated learning. Neuron 24:401-414.

Nakamura T, Sanokawa R, Sasaki Y, Ayusawa D, Oishi M, Mori N (1996) N-Shc: a neural-specific adapter molecule that mediates signaling from neurotrophin/Trk to Ras/MAPK pathway. Oncogene 13:111-119.

Ortiz J, Harris HW, Guitart X, Terwilliger RZ, Haycock JW, Nestler EJ (1995) Extracellular signal-regulated protein kinases (ERKs) and ERK kinase (MEK) in brain: regional distribution and regulation by chronic morphine. J Neurosci 15:1285-1297.

Otani S, Abraham WC (1989) Inhibition of protein synthesis in the dentate gyrus, but not the entorhinal cortex, blocks maintenance of long-term potentiation in rats. Neurosci Lett 106:175-180.

Patterson SL, Pittenger C, Morozov A, Martin KC, Scanlin H, Drake C, Kandel ER (2001) Some forms of cAMP-mediated long-lasting potentiation are associated with release of BDNF and nuclear translocation of phospho-MAP kinase. Neuron 32:123-140.

Pizzorusso T, Ratto GM, Putignano E, Maffei L (2000) Brain-derived neurotrophic factor causes cAMP response element-binding protein phosphorylation in absence of calcium increases in slices and cultured neurons from rat visual cortex. J Neurosci 20:2809-2816.

Roberts LA, Higgins MJ, O'Shaughnessy CT, Stone TW, Morris BJ (1996) Changes in hippocampal gene expression associated with the induction of long-term potentiation. Brain Res Mol Brain Res 42:123-127.

Robinson MJ, Harkins PC, Zhang J, Baer R, Haycock JW, Cobb MH, Goldsmith EJ (1996) Mutation of position 52 in ERK2 creates a nonproductive binding mode for adenosine $5^{\prime}$-triphosphate. Biochemistry 35:5641-5646.

Rosenblum K, Meiri N, Dudai Y (1993) Taste memory: the role of protein synthesis in gustatory cortex. Behav Neural Biol 59:49-56. 
Rosenblum K, Futter M, Jones M, Hulme EC, Bliss TVP (2000) ERKI/II regulation by the muscarinic acetylcholine receptors in neurons. J Neurosci 20:977-985.

Schagger H, von Jagow G (1987) Tricine-sodium dodecyl sulfatepolyacrylamide gel electrophoresis for the separation of proteins in the range from 1 to $100 \mathrm{kDa}$. Anal Biochem 166:368-379.

Schuman EM (1999) Neurotrophin regulation of synaptic transmission. Curr Opin Neurobiol 9:105-109.

Seger R, Krebs EG (1995) The MAPK signaling cascade. FASEB J 9:726-735.

Thomson S, Mahadevan LC, Clayton AL (1999) MAP kinase-mediated signalling to nucleosomes and immediate-early gene induction. Semin Cell Dev Biol 10:205-214.

Walz R, Roesler R, Quevedo J, Sant'Anna MK, Madruga M, Rodrigues C, Gottfried C, Medina JH, Izquierdo I (2000) Time-dependent im- pairment of inhibitory avoidance retention in rats by posttraining infusion of a mitogen-activated protein kinase kinase inhibitor into cortical and limbic structures. Neurobiol Learn Mem 73:11-20.

Winder DG, Martin KC, Muzzio IA, Rohrer D, Chruscinski A, Kobilka B, Kandel ER (1999) ERK plays a regulatory role in induction of LTP by theta frequency stimulation and its modulation by beta-adrenergic receptors. Neuron 24:715-726.

Wisden W, Errington ML, Williams S, Dunnett SB, Waters C, Hitchcock D, Evan G, Bliss TV, Hunt SP (1990) Differential expression of immediate early genes in the hippocampus and spinal cord. Neuron 4:603-614.

Ying SW, Futter M, Rosenblum K, Webber M, Hunt SP, Bliss TVP, Bramham CR (2002) BDNF induces LTP in intact adult hippocampus: requirement for ERK activation coupled to CREB and upregulation of Arc synthesis. J Neurosci 22:1532-1540. 